\title{
Pelatihan Pembuatan Sabun Cuci Piring dan Sabun Detergent Bagi Masyarakat Desa Senyiur Kec. Keruak Lombok Timur
}

\author{
Intan Kusuma Wardani \\ Dosen Pendidikan Olahraga dan Kesehatan, Universitas Pendidikan Mandalika, \\ intankusumawardani@ikipmataram.co.id
}

\begin{abstract}
Abstrak--Program Penerapan IPTEKS ini berjudul "Pelatihan Pembuatan Sabun Cair Pencuci Piringdan Sabun Detergent bagi Masyarakat Desa Senyiur Kec.Keruak Lombok Timur." Usaha sabun cuci piring dan sabun detergent ini termasuk satu usaha kecil, tapi memiliki potensi yang besar karena kebutuhan konsumsi akan sabun cuci piring dan sabun detergent di masyarakat cukup tinggi, di antaranya untuk keperluan rumah tangga. Permasalahan yang dihadapi oleh mitra/masyarakat adalah masih banyak ibu rumah tangga yang tidak tahu melakukan kegiatan untuk menunjang penambahan perekonomian keluarga dan kurangnya pendapatan ibu rumah tangga sehingga untuk membeli sesuatu harus memilih dan memilah dengan kebutuhan keluarganya. Oleh karena itu, pengabdian ini bertujuan untuk meningkatkan pendapatan masyarakat dengan berwirausaha dalam membuat sabun pencuci piring dan sabun detergent dan melatih para ibu-ibu rumah tangga di desa senyiur untuk membuat sabun pencuci piring dan sabun detergent secara mandiri atau home industri untuk keperluan rumah tangga.Adapun tahapan yang dilakukan dalam pelaksanaan pengabdian ini adalah: (a) tahap Pendekatan Persuasif/Persiapan, (b) tahap Pembinaan dan Pelatihan; materi yang akan dibekalkan kepada peserta pelatihan adalah materi pelatihan dalam bentuk teori dan video, dan (c) tahap Pelaksanaan Evaluasi. Dapat disimpulkan bahwa setiap kelompok sudah dapat membuat sabun cair pencuci piring dan sabun detergent dengan benar dan pengadukannya juga sudah tepat sesuai dengan takaran waktu yangdiberikan.
\end{abstract}

Kata Kunci: pelatihan, sabun cair pencuci piring, sabun cair detergent

\section{PENDAHULUAN}

\section{Analisis Situasi}

Sabun sebagai salah satu kebutuhan utama untuk mendapatkan standar kebersihan yang baik dalam kehidupan sehari-hari termasuk dalam kebutuhan pokok, tetapi sabun tidak termasuk dalam kelompok kebutuhan primer. Pemenuhan akan sabun seringkali dianggap sebagai kebutuhan sekunder, karena kebutuhan primer (sandang, pangan, papan) merupakan kebutuhan yang wajib untuk dipenuhi setiap hari. Konsumsi sabun yang terus menerus setiap harinya, menyebabkan kebutuhan pengadaan sabun yang membutuhkan biaya yang tidak sedikit. Dalam menjalankan usaha pembuatan jajan sederhana, sabun yang selama ini digunakan untuk mencuci piring adalah sabun colek dengan harga $\mathrm{Rp} 2.600$,- per sachet per hari. Penyediaansabun sachet untuk 1 bulan membutuhkan biaya sebanyak Rp 52.000,Hal ini menunjukkan bahwa masyarakat harus menyediakan dana minimal Rp 52.000,- per bulan untuk pengadaan sabun yang diperlukan untuk membersihkan peralatan memasak. Tujuan kegiatan pelatihan ini adalah untuk memberikan pengetahuan dan pelatihan tentang pembuatan sabun cuci piring cair dan untuk melatih kewirausahaan kreatif

Membuat sabun cuci piring dan sabun detergent ini bisa dilakukan sendiri. Cairan yang dibuat ini merupakan sabun yang berbentuk cair yang khusus untuk membersihkan peralatan makan dan peralatan dapur lainnya serta untuk mecuci pakaian. Bahan-bahan yang dipakai juga merupakan bahan-bahan yang ramah lingkungan[3]. Kualitas cairan yang dihasilkan juga dapat membersihkan secara sempurna. Selain itu, cara membuatnya pun tidak rumit sehingga dapat dibuat oleh siapa pun [4].

Berdasarkan survei awal diperoleh gambaran bahwa banyak masyarakat di Desa Senyiur belum memiliki usaha kecil-kecilan 
dalam menambah pendapatan mereka. Selain itu, masyarakat masih kurang pengetahuan dan wawasan dalam hal teknologi. Hal ini sering terjadi sehingga banyak masyarakat yang hanya menghabiskan waktu denganmengerjakan pekerjaan rumahan saja secara rutin. Tentu saja yang paling utama untuk bisa menjadi maju adalah adanya keterampilan yang dimiliki oleh masyarakat terutama ibu-ibu di Desa Senyiur ini.

\section{PermasalahanMitra}

Kegiatan pelatihan pembutan sabun cuci piring pada masyarakat meliputi identifikasi permasalahan yang muncul pada masyarakat sesuai dengan kompetensi masyarakat bersangkutan. Permasalahan tersebut yang selanjutnya dikaji dan dicarikan solusi. Metode pendekatan untuk dapat menyelesaikan permasalahan dalam kegiatan ini menggunakan metode Participatory Action Research (PAR). Solusi yang ditawarkan pada kegiatan pelatihan pada masyarakat ini berupa pemberian penyuluhan dengan materi yang telah ditentukan. Bahan-bahan pembuatan sabun dapat dengan mudah ditemukan di toko kimia terdekat. Bahan dasar pembuatan sabun cair meliputi SLS, texapon dan garam serta bahan aditif seperti parfum, pengawet, pengental dan zat pewarna.

Berdasarkan analisis situasi yang telah dipaparkan di atas, permasalahan yang dihadapi oleh mitra/masyarakat adalah.

1. Masih banyak ibu rumah tangga yang tidak tahu melakukan apa untuk menunjang penambahan perekonomiankeluarga.

2. Kurangnya pendapatan ibu rumah tangga sehingga untuk membeli sesuatu harus memilih dan memilah dengan kebutuhan keluarganya.

\section{Solusi Yang Ditawarkan}

Upaya awal yang dapat dilakukan adalah memberikan pengetahuan dan keterampilan kepada mitra/masyarakat terutama Ibu Rumah Tangga (IRT) sebagai bekal untuk menunjang perekonomian keluarga. Motivasi awalnya adalah bahwa IRT mendapat keterampilan dalam membuat sabun cair sehingga dapat meningkatkan pendapatan mereka. Pengetahuan dan keterampilan tesebut diberikan dengan mengenalkan dan memberikan pengetahuan mengenai pembuatan sabun cair secara lengkap danaplikatif.

Berdasarkan hal tersebut, dilakukanlah suatu pembinaan sebagai penanganan atas kendala IRT dalam hal menunjang pendapatan ekonomi keluarganya. Kegiatanpelatihan ini diharapkan menjadi solusi bagi mereka untuk menjadi lahan bisnis yang bagus.

\section{METODE PELAKSANAAN}

\section{Bahan dan Metode}

Bahan yang digunakan di dalam pelatihan ini terdiri dari bahan dasar pembuatan sabun cair meliputi SLS, texapon dan garam serta bahan aditif seperti parfum, pengawet, pengental dan zat pewarna. Kegiatan pengabdian ini menggunakan dua metode yang dijabarkan dalam prosedur kerja, yaitu:

1. metode ceramah atau orasi yang akan disampaikan oleh ketuatim;

2. metode demonstrasi dan praktik tentang proses pembuatan sabuncair.

ProsedurKerja

Kegiatan pengabdian ini terdiri dari empat tahap. Tahap pertama akan dilakukan pertemuan dan mengkoordinasikan dengan pihak kepala desa dan kelompok ibu-ibu yang akan melakukan pembuatan sabun cair. Dari hasil pertemuan dilakukan proses tahap kedua yaitu kegiatan penyusunan materi dan persiapan metode praktik.

Tahap ketiga yaitu Tahap Pembinaan dan Pelatihan. Pada saat pelatihan materi yang akan dibekalkan kepada peserta pelatihan adalah materi pelatihan dalam bentuk teori dan demonstrasi. Pelaksanaan kegiatan ini dilakukan selama 1 bulan untuk Ibu Rumah Tangga (IRT) Desa Senyiur, Kecamatan Keruak. Dalam hal ini peserta pelatihan dikelompokkan agar memudahkan proses pelatihan.

Tahap keempat yaitu, Tahap Pelaksanaan Evaluasi. Setelah tahap pelatihan (demonstrasi), dilanjutkan dengan tahap evaluasi. Dalam tahap ini, kegiatan diarahkan untuk mengukur kompetensi masing-masing 
peserta pelatihan terhadap materi yang diajarkan dan hasil yang didapatkan setelah meracik bahan-bahan dalam pembuatan sabun ini. Dalam proses evaluasi, tim pengabdian melakukan evaluasi dengan mengunjungi setiap kelompok pada saat pembuatan sabun perminggu selama sebulan.

\section{HASIL DANPEMBAHASAN \\ Tahapan Pelaksanaan Kegiatan}

Jumlah peserta pelatihan sebanyak 40 orang. Keseluruhan peserta tersebut berasal dari berbagai profesi ada yang berprofesi sebagai IRT dan ada juga yang berprofesi sebagai guru. Keseluruhan peserta tersebut terlibat secara interaktif dengan kedua instruktur pengabdian yang mendampingi.

Berbagai permasalahan dan kendala dikemukakan secara lugas oleh peserta mengenai langkah selanjutnya dalam pembuatan sabun cair dan pemasarannya. Para peserta terlihat antusias dalam hal ini mungkin karena sabun yang dihasilkan dapat bermanfaat bagi mereka dan juga aman untuk kesehatan.

Instruktur pengabdian menjelaskan secara detail mengenai cara mengaduk bahan sabun, takarannya, dan waktunya sehingga menghasilkan sabun yang sesuai. Bahkan, instruktur juga mengatakan bahwa jika ada peserta yang memilikikendala dalam pembelian keperluan dan bahan untuk pembuatan sabun ini, instruktur akan membantu mengarahkan atau membantu membelikan melalui distributor terdekat.

\section{Evaluasi Kegiatan}

Secara umum kegiatan pengabdian masyarakat berjalan dengan baik dan lancar. Sampai dengan akhir kegiatan seluruh peserta hadir sesuai dengan jadwal yang telah ditentukan. Dampak kegiatan telah terlihat seiring peserta dapat meracik bahan-bahan dan mencampurkan air sesuai dengan takarannya dan mengaduk sesuai dengan waktu yang ditentukan. Masing-masing peserta dikelompokkan menjadi 5 kelompok. Masing-masing kelompok terdiri dari 4 orang. Masing-masing kelompok sudah bisa meracik bahan, mengaduk, dan menentukan waktu dengan benar. Output pelatihan ini terlihat dengan jelas. Setiap kelompok diminta untuk unjuk kerja dalam menghasilkan sabun cair sesuai dengan takaran yang telah ditentukan. Kemudian para instruktur melakukan evaluasi serta memberikan saran-saran perbaikan terhadap hasil kerja mereka. Komunikasi antara peserta dengan instruktur terus terjalin meskipun secara tatap muka dinyatakan telahselesai.

Kegiatan pengabdian ini perlu dilakukan secara berkesinambungan. Banyaknya minat dari para peserta dapat diakomodasi seiring dengan keterbatasan dana yang dialokasikan oleh lembaga. Akibatnya, kegiatan ini dilaksanakan hanya tiga pertemuan saja, tetapi proses pengabdian secara nonformal tetap dilanjutkan di luar pertemuan tersebut. Para instruktur dalam kurun waktu 3 minggu terus mendatangi tiap kelompok yang diwakilkan oleh ketua kelompok untuk melihat perkembangan dari peserta dalam menghasilkan sabun cair sebagai evaluasi bagi timpengabdian. pelatihan.

Berikut beberapa foto kegiatan

Gambar 1. Instruktur sedang memperlihatkan bahan-bahan

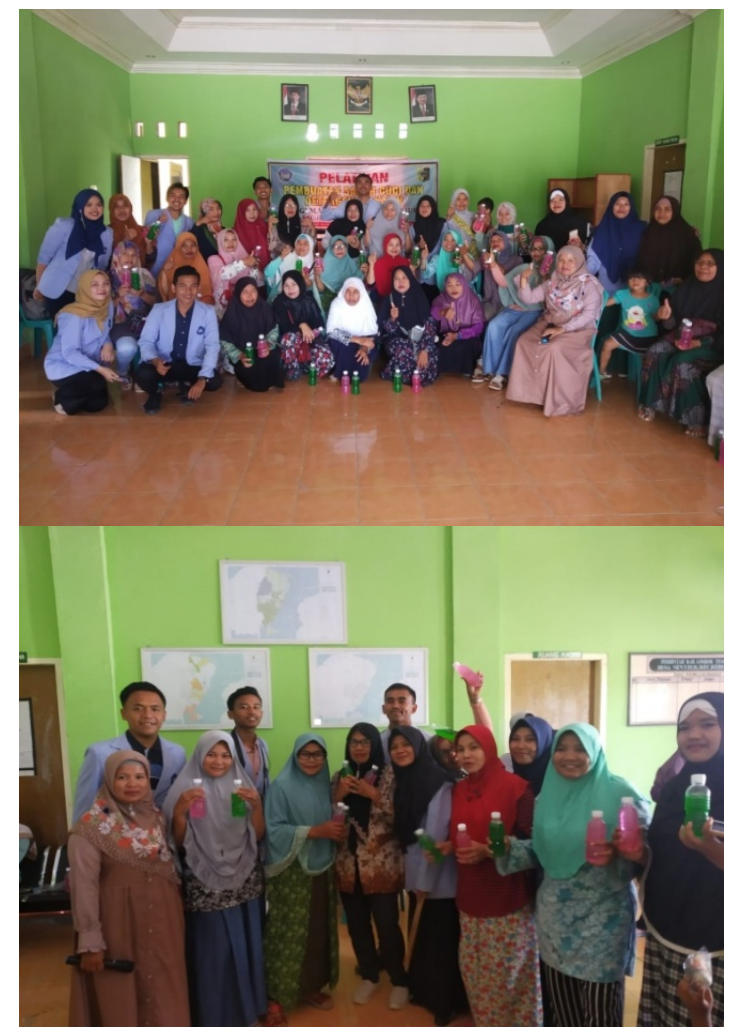




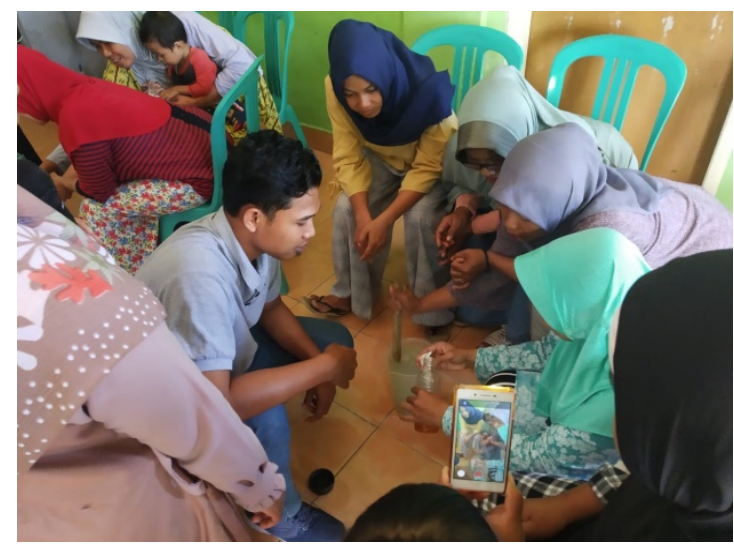

\section{SIMPULAN}

Secara umum pelaksanaan Pelatihan Dasar Pembuatan Sabun Cair Pencuci Piring bagi IRT Gampong Mesjid Puentuet telah dilaksanakan dengan baik. Para peserta telah dilatih cara menentukan baha-bahan dasar pembuatan sabun, menetukan takaran dan waktunyanya, dan cara pengadukaannya. Dengan adanya pelatihan ini IRT Gampong Mesjid Puentuet dapat:

a. melakukan suatu kegiatan yang bermanfaat untuk menunjang perekonomian keluarga;

b. memiliki tambahan ilmu dan wawasan salah satunya pengetahuan dan keterampilan tentang pembuatan sabun cair pencuci piring;

c. dapat memasarkan produk ini kepada distributor terdekat.

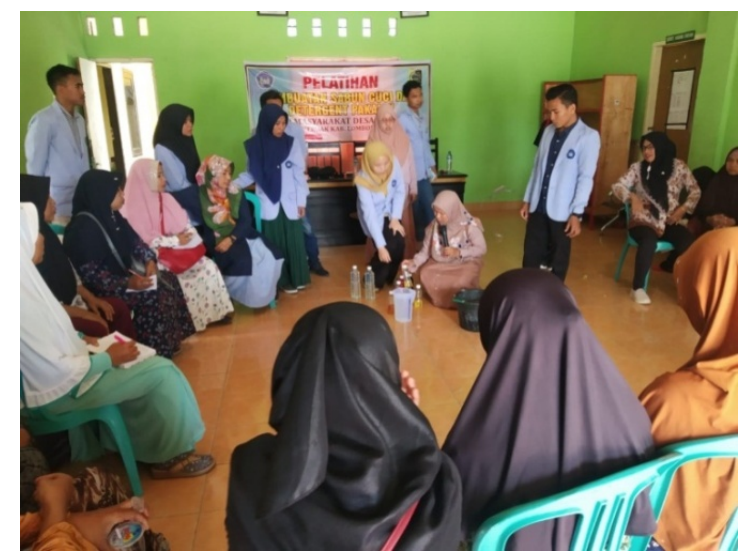

\section{REFERENSI}

[1] Haryanto, Tri.1994. Membuat Sabun dan Deterjen. Jakarta: Penebar Swadaya.

[2] Prawironegoro, Wijayokusumo. 1978. Resep-Resep Industri Jilid I. Yogyakarta: PTNurcahya.

[3] Soegeng.1975. Seri Industri, pendidikan Keterampilan Jenis Barang-Barang keperluan Sehari-hari. Jakarta: PT KaryaNusantara.

[4] Pgalihteapgalihtea. 2015. 3 Manfaat Formula Sabun Cair Cuci piring dari Sunlight.https://baritako.wordpress.com/2 015/06/26/3-manfaat- formula-sabuncair-cuci-piring-dari-sunlight/, diakses tanggal 9 Februari 2017. 